DOI: http://dx.doi.org/10.1590/S0104-64972015002301

\title{
High taxonomic resolution as a determinant on finding new species and new records in the Río de La Plata basin: a case on Chydoridae (Crustacea: Branchiopoda: Cladocera)
}

José Roberto Debastiani-Júnior, Lourdes Maria Abdu Elmoor-Loureiro and Marcos Gomes Nogueira

(JRDJr) (MGN) Departamento de Zoologia, Universidade Estadual Paulista - Unesp, Rubião Júnior, s/n, 18618-970 Botucatu, São Paulo, Brazil. E-mail: (JRDJr) debastianijunior@gmail.com

(LMAEL) Laboratório de Biodiversidade Aquática, Universidade Católica de Brasília, QS 7 lot 1, room M204, 71966-700 Taguatinga, DF, Brazil

\begin{abstract}
Recent worldwide taxonomical research on Cladocera is discovering a number of new species but hardly in South America. The Río de La Plata is the second largest basin in the continent and the knowledge on cladocerans of the different sub-basins is uneven. The recent increase in the number of cladocerans species worldwide inspired this survey in the Río de La Plata basin. It was expected that new species, or at least a significant number of new records, could be found which would contribute to the richness of the least studied sub-basins. Twenty three sampling locations were selected and the Cladocera were analyzed in detail to the species level. The family Chydoridae was targeted due to its high species richness. Fifty species of Chydoridae were recorded, two of them probably new for science and a third one whose taxonomical status could not be further addressed, due to insufficient material for analysis. All sub-basins had at least one specimen of one or both new species. The contribution of new species was more homogeneous among subbasins when compared to the total contribution of new registers. It was concluded that the improvement of the taxonomical resolution and extensive samplings are fundamental in assessing the real cladoceran richness in the basin and that knowledge based on just a few research centers is not enough to promote secure taxonomical and biogeographical considerations yet.
\end{abstract}

Key words: Phytophilous cladocerans, Geographical distribution, Taxonomy, Biogeography

\section{INTRODUCTION}

Research on cladoceran taxonomy is being carried out all around the world. The high taxonomical resolution used in the researches has resulted in a continuous increase in the number of known species and reallocation of former taxa into new groups (e.g. Van Damme and Dumont, 2010; Van Damme et al., 2011).

Cladocera investigation in South America and some other continents (Chatterjee et al., 2013) has historically focused on the ecology of the group, rather than on taxonomical investigation. Due to this bias, contemporary research that applies a higher level of resolution for the taxa identification is frustrating as there are inconsistencies and many unidentified species.
There is not only a historical lack of taxonomical knowledge, but also a marked heterogeneity in the geographical distribution of the studies, which are concentrated around scientific centers. Many of these centers are in the Río de La Plata basin, the second largest basin in South America and densely populated. In this basin, it is possible to find relatively well studied regions, such as the middle Paraná River sub-basin (e.g. José de Paggi and Paggi, 2007), but also almost unstudied regions as the Paraguay River sub-basin, directly connected to the Pantanal, an extensive wetlandfloodplain system.

The worldwide increasing number of species and constant reallocation of taxa and the regional lack of taxonomical studies created a knowledge 
vacuum on Cladocera in the Río de La Plata basin and inspired a comprehensive survey.

In this paper, only the family Chydoridae Stebbing, 1902 was addressed due to their likely high species richness. Additionally, this family is also subject of recent taxonomical studies which provides a large amount of new information to be considered in the identification process.

Based on the above cited geographical organization of knowledge in the basin, it was expected to find a higher proportion of new species and new records in less-studied regions of the basin.

\section{MATERIAL AND Methods}

Cladocerans were sampled with plankton net $(68$ $\mu \mathrm{m})$, in 23 macrophyte-rich sites of the Río de La Plata basin during summer and winter 2010 (Fig. 1). Table 1 lists the sampling sites by region, their coordinates and level of knowledge evaluation.
The identification of Chydoridaewas performed on the basis of exhaustive morphological analyses, at species level, based on specialized literature (e.g. Smirnov, 1996; Elmoor-Loureiro, 1997; Van Damme and Dumont, 2008; Van Damme et al., 2011).

The relative contribution of new taxa and new records were represented by their proportion in the total number of species sampled in each region.

\section{RESULTS}

A total of 50 species of Chydoridae was found in this study (Tab. 2).

Two possible new species of Chydoridae are proposed, both presently being described. The first species belongs to Alona Baird, 1843 sensu lato, which include the Alona-like species that cannot be placed into true genus Alona (Van Damme and Dumont, 2008) (Fig. 2). The second species (Fig. 3) shared many features with Anthalona simplex

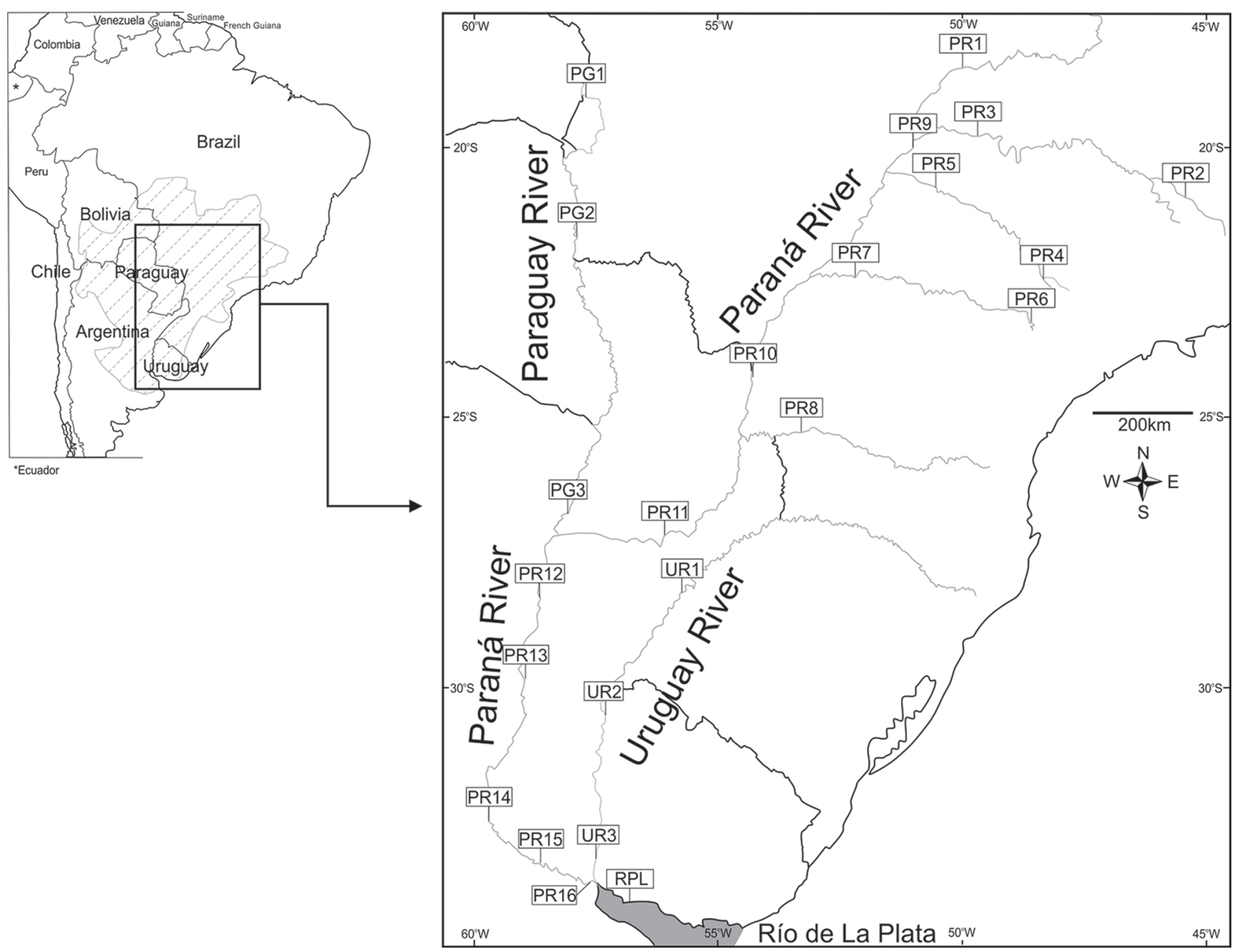

Figure 1. Sampling sites distribution in the Río de La Plata basin. PR1-10 = Upper Paraná sub-basin; PR11-13 = Middle Paraná sub-basin; PR14-16 = Low Paraná sub-basin; PG = Paraguay sub-basin; UR = Uruguay sub-basin; RPL = Río de La Plata. 
Table 1. Study sites with codes, geographical position, sub-basin and level of knowledge concerning Cladocera from Río de La Plata basin.

\begin{tabular}{|c|c|c|c|c|}
\hline Code & Latitude & Longitude & Sub-Basin & Knowledge \\
\hline PR1 & $18^{\circ} 42^{\prime} 23.59^{\prime \prime S}$ & $50^{\circ} 02^{\prime} 28.25^{\prime \prime} \mathrm{W}$ & \multirow{10}{*}{ Upper Paraná } & \multirow{10}{*}{$\begin{array}{l}\text { Well studied: Lansac-Tôha et al.(1997), Rocha } \\
\text { and Güntzel (1999), Lima et al. (2003), } \\
\text { Perbiche-Neves and Nogueira (2010), Rocha } \\
\text { et al. (2011) etc. }\end{array}$} \\
\hline PR2 & $20^{\circ} 58^{\prime} 39.97 ” \mathrm{~S}$ & $45^{\circ} 31^{\prime} 33.05^{\prime \prime} \mathrm{W}$ & & \\
\hline PR3 & $19^{\circ} 56^{\prime} 51.47^{\prime \prime S}$ & $49^{\circ} 44^{\prime} 51.51^{\prime \prime W}$ & & \\
\hline PR4 & $20^{\circ} 11^{\prime} 42.10^{\prime \prime} \mathrm{S}$ & $50^{\circ} 59^{\prime} 04.82^{\prime \prime W}$ & & \\
\hline PR5 & $22^{\circ} 41^{\prime} 03.74 " \mathrm{~S}$ & $48^{\circ} 22^{\prime} 00.77^{\prime \prime} \mathrm{W}$ & & \\
\hline PR6 & $20^{\circ} 55^{\prime} 34.36^{\prime \prime} \mathrm{S}$ & $50^{\circ} 34^{\prime} 33.65^{\prime \prime} \mathrm{W}$ & & \\
\hline PR7 & $23^{\circ} 28^{\prime} 23.66^{\prime \prime S}$ & $48^{\circ} 38^{\prime} 23.56^{\prime} \mathrm{W}$ & & \\
\hline PR8 & $22^{\circ} 38^{\prime} 02.87^{\prime \prime} \mathrm{S}$ & $52^{\circ} 09^{\prime} 39.88^{\prime \prime} \mathrm{W}$ & & \\
\hline PR9 & $25^{\circ} 30^{\prime} 30.60^{\prime \prime} \mathrm{S}$ & $53^{\circ} 17^{\prime} 34.35^{\prime \prime} \mathrm{W}$ & & \\
\hline PR10 & $24^{\circ} 29^{\prime} 57.44^{\prime \prime} \mathrm{S}$ & $54^{\circ} 17^{\prime} 51.79^{\prime \prime} \mathrm{W}$ & & \\
\hline PR11 & $27^{\circ} 26^{\prime} 20.04^{\prime \prime S}$ & $56^{\circ} 14^{\prime} 30.16^{\prime \prime W}$ & \multirow{3}{*}{ Middle Paraná } & \multirow{3}{*}{$\begin{array}{l}\text { Well studied: Paggi }(1972 ; 1973 ; 1975 ; 1995 ; \\
\text { 2004), José de Paggi and Paggi (2007), Paggi } \\
\text { and José de Paggi (1974; 1990) etc. }\end{array}$} \\
\hline PR12 & $28^{\circ} 29^{\prime} 33.95^{\prime \prime} \mathrm{S}$ & $59^{\circ} 02^{\prime} 24.47^{\prime \prime W}$ & & \\
\hline PR13 & $30^{\circ} 00^{\prime} 54.59^{\prime \prime} \mathrm{S}$ & $59^{\circ} 32^{\prime} 51.93 ” \mathrm{~W}$ & & \\
\hline PR14 & $32^{\circ} 44^{\prime} 07.16^{\prime \prime} \mathrm{S}$ & $60^{\circ} 43^{\prime} 10.12^{\prime \prime W}$ & \multirow{3}{*}{ Low Paraná } & \multirow{3}{*}{$\begin{array}{l}\text { In need of studies: Paggi (2004) shows general } \\
\text { information for all Argentina. }\end{array}$} \\
\hline PR15 & $33^{\circ} 40^{\prime} 49.00^{\prime \prime} \mathrm{S}$ & $59^{\circ} 38^{\prime} 48.80^{\prime \prime} \mathrm{W}$ & & \\
\hline PR16 & $33^{\circ} 56^{\prime} 49.45^{\prime \prime} \mathrm{S}$ & $58^{\circ} 27^{\prime} 07.47^{\prime \prime} \mathrm{W}$ & & \\
\hline PG1 & $18^{\circ} 58^{\prime} 48.29^{\prime \prime} \mathrm{S}$ & $57^{\circ} 38^{\prime} 26.26^{\prime \prime} \mathrm{W}$ & \multirow{3}{*}{ Paraguay } & \multirow{4}{*}{$\begin{array}{l}\text { In need of studies: Frutos et al. (2006) have a } \\
\text { large spatial range; Espíndola et al. (1996) have } \\
\text { no Chydoridae identification; Neves et al. (2003) } \\
\text { and Güntzel et al. (2010) show species lists }\end{array}$} \\
\hline PG2 & $21^{\circ} 40^{\prime} 41.13^{\prime \prime S}$ & $57^{\circ} 53^{\prime} 25.21^{\prime \prime} \mathrm{W}$ & & \\
\hline PG3 & $26^{\circ} 52^{\prime} 10.45^{\prime \prime} \mathrm{S}$ & $58^{\circ} 19^{\prime} 54.12^{\prime \prime W}$ & & \\
\hline UR1 & $28^{\circ} 29^{\prime} 35.23^{\prime \prime S}$ & $55^{\circ} 58^{\prime} 17.53^{\prime \prime W}$ & \multirow{3}{*}{ Uruguay } & \\
\hline UR2 & $30^{\circ} 44^{\prime} 57.60$ ”S & $57^{\circ} 44^{\prime} 37.31^{\prime \prime W}$ & & \multirow[t]{2}{*}{ No work on Chydoridae was found } \\
\hline UR3 & $33^{\circ} 49^{\prime} 40.48^{\prime \prime S}$ & $58^{\circ} 25^{\prime} 41.52^{\prime \prime W}$ & & \\
\hline RPL & $34^{\circ} 25^{\prime} 38.85^{\prime \prime} \mathrm{S}$ & $57^{\circ} 34^{\prime} 40.75^{\prime \prime W}$ & - & - \\
\hline
\end{tabular}

Van Damme, Sinev \& Dumont, 2011 (Van Damme et al., 2011) and, thus, is considered to belong to this genus. A third possible new species is listed [Tab. 2, Chydorus sp. (?)], but due to lack of material for detailed analysis, no further consideration could be performed.

The percentage contribution of new taxa and new records to the total richness observed per region is recorded in Fig. 4. Each of the two new species is widespread, occurring in 4 of the 5 sub-basins (Tab. 2), but neither occurs in the Río de La Plata itself, whose fauna was composed of Chydorus pubescences Sars, 1901, Ephemeroporus acanthodes Frey, 1982, Euryalona orientalis (Daday, 1898), Karualona muelleri (Richard, 1897), Kurzia polyspina Hudec, 2000, Leydigia striata Berabén, 1939, Nicsmirnovius sp. and Picripleuroxus cf. similis (Vávra, 1900).

\section{Discussion}

The main objective of this study was to perform an inventory of the Cladocera of the Río de La Plata basin and to analyze the contribution of new species to the fauna of different regions of the basin considered as having contrasting degrees of knowledge.
A large number of species was identified, many of them with taxonomic uncertainties.

This is in agreement with other recent research whose data suggest that Alona broaensis Smirnov and Matsumura-Tundisi, 1984 and Alona dentifera (Sars, 1901) are probable synonyms (Van Damme et al., 2010), Coronatella cf. poppei (Richard, 1897) is a species complex being described (Sousa, unpublished data) and Nicsmirnovius sp. probably constitutes a new species in Brazil (Sousa et al., 2012). It is important to note that Nicsmirnovius sp. does not correspond to the two known species from Americas: Nicsmirnovius incredibilis (Smirnov, 1984) and Nicsmirnovius fitzpatricki (Chien, 1970). Both N. fitzpatricki and Nicsmirnovius sp. are easily distinguished from $N$. incredibilis by the shape and armature of the postabdomen; while $N$. incredibilis has two distal angles and marginal clusters of setules, $N$. fitzpatricki and Nicsmirnovius sp. present a single distal angle and marginal denticles. Nicsmirnovius sp. differs from N. fitzpatricki in features of the trunk limbs (Sousa et al., 2012). 
Table 2. Species list with presence/absence of each species and total richness by sub-basin. UPR = Upper Paraná, MPR = Middle Paraná, LPR = Low Paraná, PG = Paraguay and UR = Uruguay. + presence; - absence. NR = New record for the Río de La Plata basin. $Y=$ yes; $N=$ no.

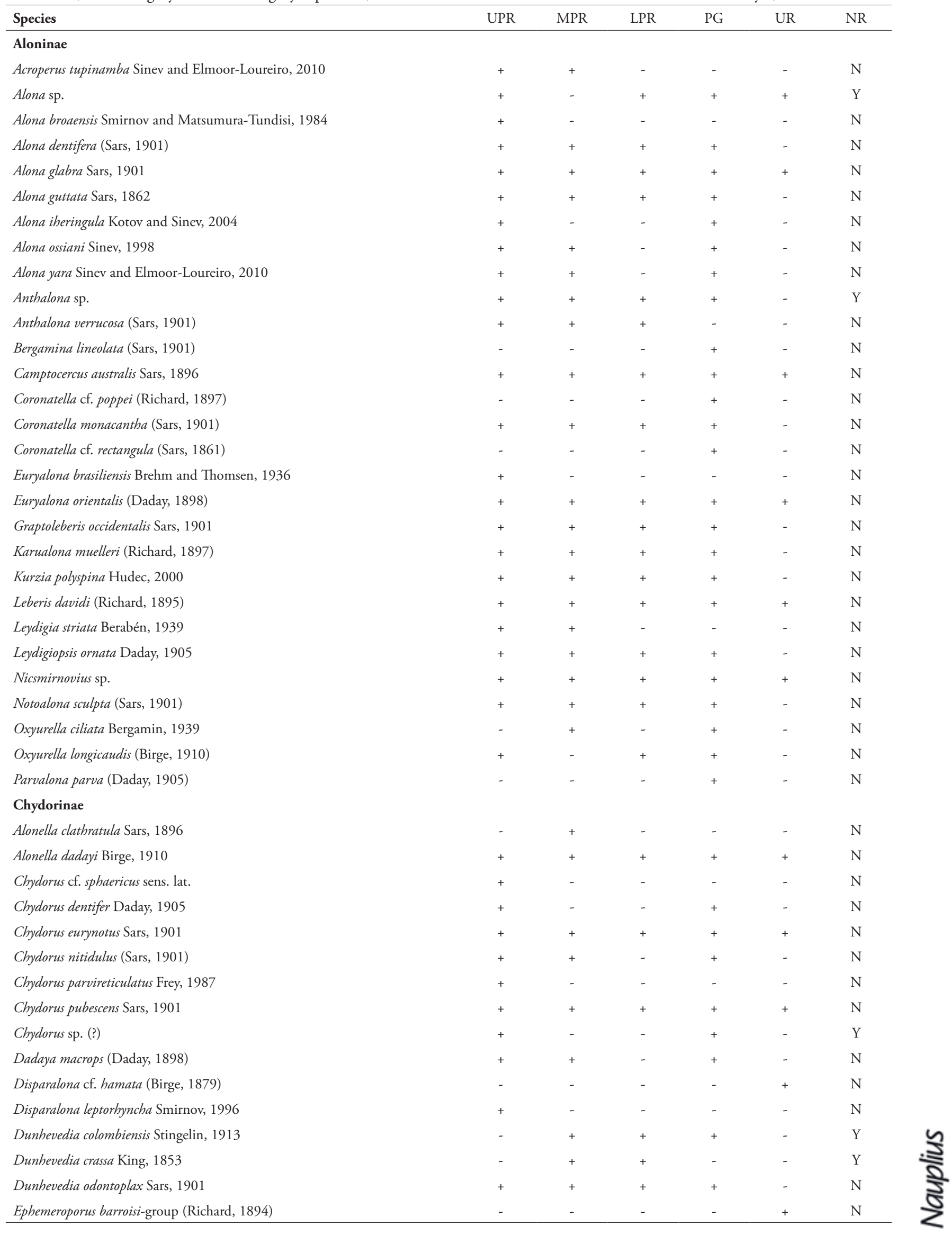


Table 2. (Cont.)

Ephemeroporus cf. acanthodes Frey, 1982

Ephemeroporus hybridus (Daday, 1905)

Ephemeroporus tridentatus (Bergamin, 1939)

Picripleuroxus cf. similis (Vávra, 1900)

Pseudochydorus globosus (Baird, 1850)

Richness

Alona guttata Sars, 1862 is probably a species complex and populations outside its type locality (Østenjǿvand, Norway) have dubious identity (Van Damme et al., 2010). Alonella lineoloata Sars, 1901 has been recently redescribed and transferred to the new genus Bergamina ElmoorLoureiro, Santos-Winiewsky \& Rocha, 2013 (Elmoor-Loureiro et al., 2013) as Bergamina lineolata. Chydorus sp. (?) is a probable new species with wide distribution in the continent since individuals with the same carapace ornamentation were found in Colombian Amazon (ElmoorLoureiro, unpublished data), but due to lack of material, it is impossible at the moment to propose with certainty a new taxonomical status. Chydorus eurynotus Sars, 1901 observed here exhibits a fold of the ventral margin of carapace similar to Chydorus ventricosus Daday, 1898, which implies the need of reevaluation of these taxa for the basin. In the present study, one individual of the genus Dunhevedia King, 1853 presented the labral keel smooth, but it clearly was in the premolt stage and a single tooth was observed on the underlying new cuticle. Nowadays, some experts describe, when possible, not only the adult female, but also the male and juveniles (for instance: Sinev \& Kotov, 2012) and the lack of information on the ontogeny is another constraint to the identification of species. Thus, it is possible that Dunhevedia odontoplax Sars, 1901 may have morphological variations during its ontogeny that resembles Dunhevedia crassa King, 1853. In addition, D. crassa and Dunhevedia colombiensis Stingelin, 1913 are new records for the basin. Ephemeroporus cf. acanthodes was described for North America, this being the first record of this species in the basin, with only one other record for South America (Lopez, 1993).

The proposal of two new species of Chydoridae in the Río de La Plata basin is based on morphological analyses: The Alona-like taxon showed ovoid body, with weak lateral compression, dorsal keel absent, arched, no posteroventral notch on valves; three main head pores, lateral pores minute; labral keel wedge-shaped to rounded and naked; postabdomen relatively short and robust, with deep pre-anal portion, unmerged marginal denticles; first limb presenting three setae; third limb with seven setae on the exopodite; fourth limb with six setae on the exopodite. In many aspects, this species resembles the members of the genus Ovalona Van Damme and Dumont, 2010. However, it also seems to be close to some American species of the Alona pulchella King, 1853-group, such as Alona altiplana Kotov, Sinev and Berrios, 2010 and Alona anamariae Sinev and Silva-Briano, 2012. This species is being described (Sousa, unpublished data). In the case of the Anthalona sp., all coarse morphological characteristics are similar to African A. simplex (Van Damme et al., 2011). Recently, Sinev and Kotov (2012) described Anthalona sanoamuang Sinev and Kotov, 2012 from Indochina, other species with morphology resembling $A$. simplex. This finding may indicate a species group with circumtropical distribution. The investigation of fine characteristics, for instance all thoracic limbs, is under development, and indicates a new species (Sousa et al., unpublished data). The investigation will allow us to obtain a better understanding of the relation among South American (this study), African (Van Damme et al., 2011) and tropical Asia (Sinev and Kotov, 2012) taxa.

The results showed a relatively high contribution of the above cited taxa to the cladoceran assemblages of the Río de La Plata basin (Fig. 4). The presence of the two possible new species in the Paraná sub-basin was a surprising result, indicating that there is still some work to be done in the regions around research centers. Their lower proportional contribution when compared to other regions was due to a higher cladoceran richness in the basin, especially in the middle Paraná stretch.

The expected presence of new species in the Paraguay sub-basin was confirmed. The wetland-floodplain system in this area has some similarities with the fluvial system of the middle 

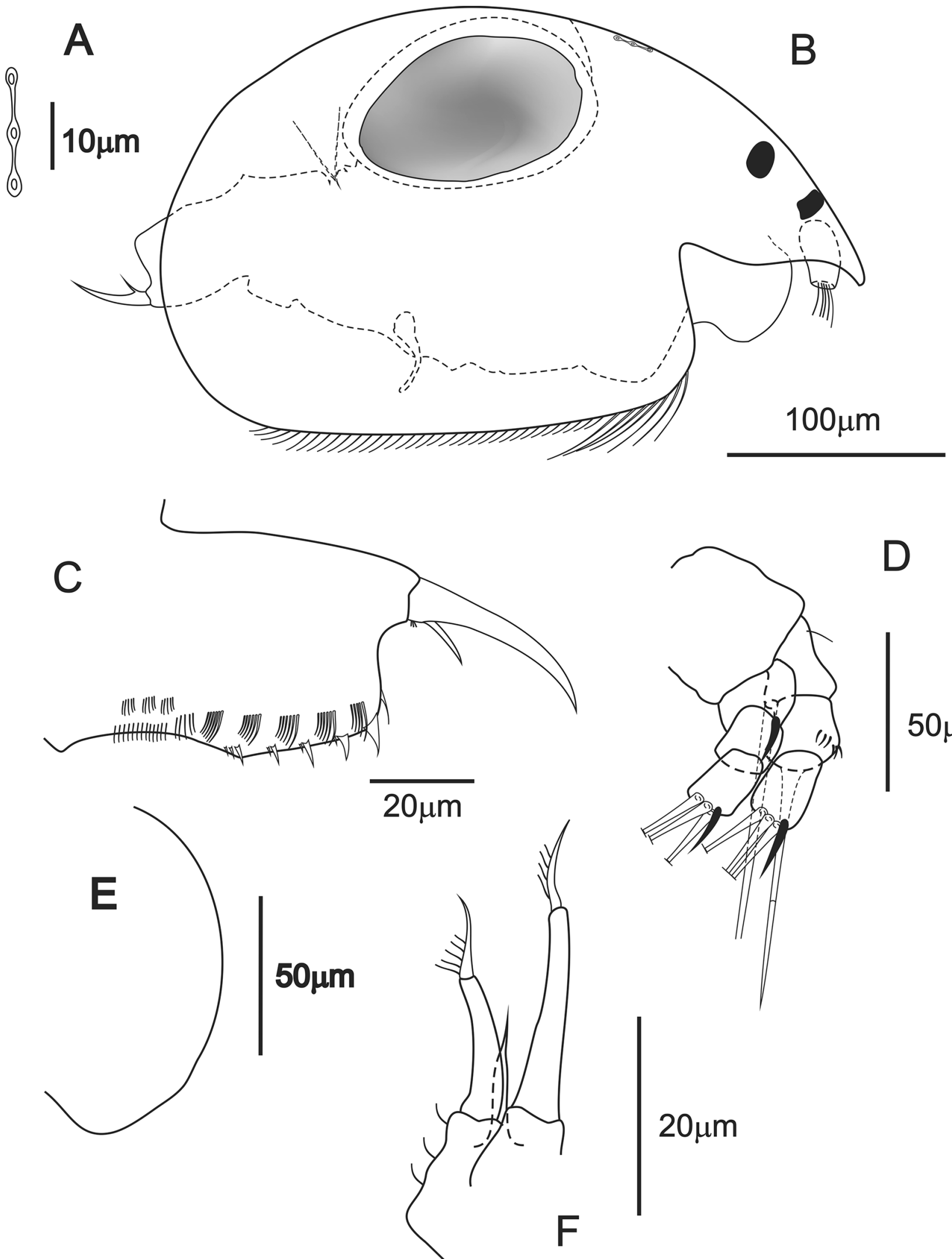

Figure 2. Alona sp. A: Main head pores; B: lateral view; C: postabdomen; D: antenna; E: labral kell; F: first limb, inner distal lobe (IDL). 

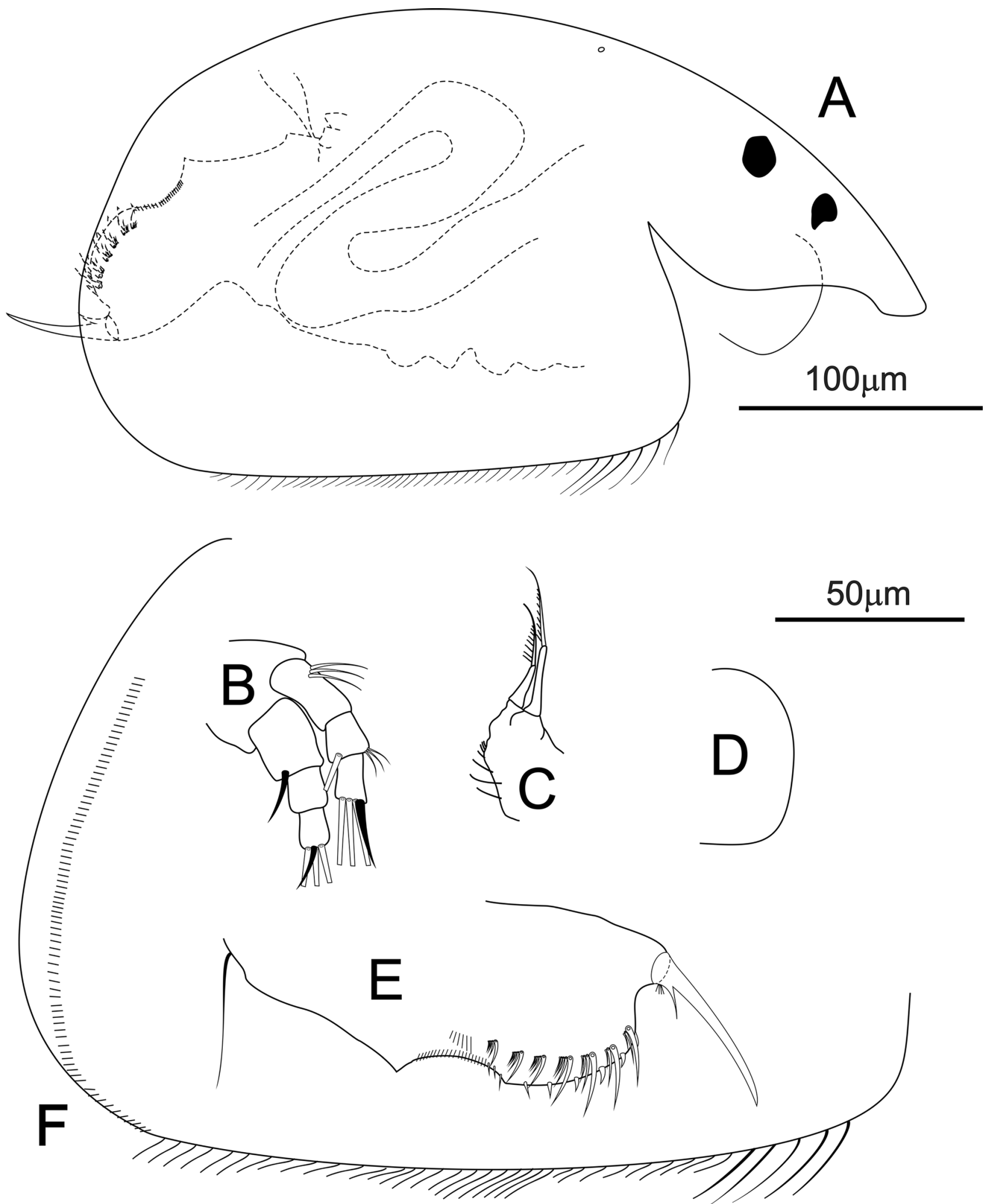

Figure 3. Anthalona sp. A: Lateral view; B: antenna; C: first limb, inner distal lobe (IDL); D: labral keel without denticle; E: postabdomen; F: ventral and posterior margins of carapace. Scale bars: $A=100 \mu \mathrm{m}$; B-F $=50 \mu \mathrm{m}$.

Paraná sub-basin, which exhibits a large richness. Therefore, the Paraguay sub-basin, and especially the Pantanal, a hotspot of biodiversity (Junk et al., 2014), is in urgent need of investigation regarding their Cladocera fauna. This type of data help to support the decision making process on definition of conservation priorities and must be readily available with easy access through the scientific literature. 


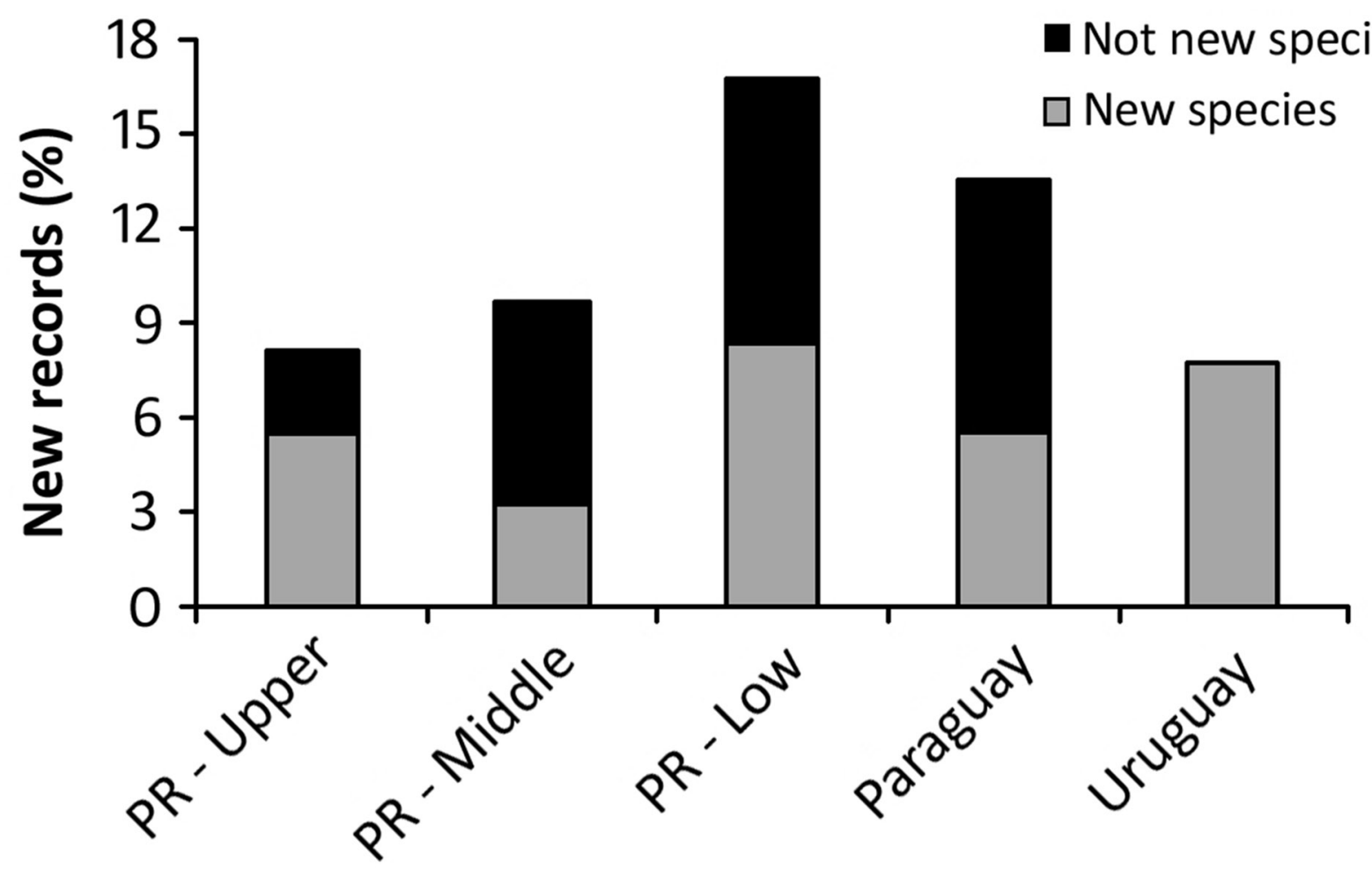

Figure 4. Relative contribution of the new records to the observed richness of the studied sub-basins. PR = Paraná.

Because it was not found any work on Chydoridae for the Uruguay sub-basin all the 13 species observed in this basin can be considered as new records for it. Nevertheless, 13 is a small number for such a large basin, being this probably an underestimate of the regional richness. For example, Serafim-Junior et al. (2006) brings a list of species from a neighbor basin containing only two overlapping species with ours (what would elevate the number to 18), what strengthens the possibility of an even higher number of actual resident species in the Uruguay sub-basin.

The sampling effort in this study could be questioned, producing as it did the typical dichotomy of wide spatial scale (geographical) and low temporal frequency. Nevertheless, the results highlight the importance of Cladocera, particularly Chydoridae, for invertebrate diversity in freshwater ecosystems of La Plata basin and how the taxonomy of this group in South America is a neglected research field when compared to other continents, especially North America and Europe where taxonomy developed earlier (Korovchinsky, 1997). In addition, it is worth noting the work of Sinev and Kotov (2012), which found new taxa in Thailand, though it is the most studied region of Indochina. Thus, the increase in taxa numbers due to higher taxonomy resolution is a worldwide phenomenon.
The resolution of identification, rather than the number of studies, seems to be a key factor determining the discovery of these taxa. This can explain the relative lack of influence of the "expected level of knowledge" on the finding of new species and highlight the need of expert taxonomists in South American Science. Chatterjee et al. (2013) discuss how taxonomic shallow analyses were detrimental to Cladocera research in India.

Nevertheless, the arrangement of the number of researches also necessarily influences the knowledge regarding Cladocera taxonomy and biogeography. For instance, Europe has a history of research that permits one to consider the continent well studied as cited above. On the other hand, other continents are recently being research targets as the cases of South America (e.g. Kotov et al., 2010; Sinev and Elmoor-Loureiro, 2010; ElmoorLoureiro et al., 2013; Sousa et al., 2013), Central America (e.g. Silva-Briano and Dumont, 2001; Elías-Gutiérrez and Valdez-Moreno, 2008; ElíasGutiérrez et al., 2001; 2006), Africa (Sinev 2009; Van Damme and Eggermont, 2011; Van Damme et al., 2013) and Asia (e.g. Kotov et al., 2013; Sinev and Korovchinsky, 2013), but these studies are not enough to represent the entire continents, with knowledge being restricted to few localities. 
This results in fragmentary knowledge that hinders the possibility of detailed biogeographical analysis due to the lack of information regarding species range in those continents.

It is concluded that high resolution analyses applied to the Cladocera identification in the Río de La Plata basin, as well as in other regions, associated to extensive samplings are a crucial factor for the finding of new species and new records and for the advancement on taxonomy and biogeography knowledge. Knowledge concentration around few research centers, focused on particular localities results in limited taxonomical and biogeographical knowledge, being not advised to make considerations before introducing more data regarding the group in the literature.

\section{ACKNOWLEDGEMENTS}

To Fundação de Amparo à Pesquisa do Estado de São Paulo (FAPESP) for financial support (processes 2009/00014-6, 2009/11781-8 and 2011/23444-6). The authors would like to thank Dr. Danilo A. O. Naliato, M.Sc. Francisco D. R. Sousa, Dr. Gilmar Perbiche-Neves, M.Sc. Jorge L. Portinho and Dr. Silvia M. C. Casanova for fieldwork support and/or valuable comments. The authors would also like to thank the anonymous reviewers who gave insightful comments to the improvement of the manuscript.

\section{REFERENCES}

Chatterjee, T.; Kotov, A.A.; Van Damme, K., Chandrasekhar, S.V.A. and Padhye, S. 2013. An annotated checklist of the Cladocera (Crustacea: Branchiopoda) from India. Zootaxa, 3667(1): 1-89.

Elías-Gutiérrez, M.; Kotov, A.A. and Garfias-Espejo, T. 2006. Cladocera (Crustacea: Ctenopoda, Anomopoda) from southern Mexico, Belize and northern Guatemala, with some biogeographical notes. Zootaxa, 1119: 1-27.

Elías-Gutiérrez, M.; Smirnov, N.N.; Suárez-Morales, E. and Dimas-Flores, N. 2001. New and little known cladocerans (Crustacea: Anomopoda) from southeastern Mexico. Hydrobiologia, 442: 41-54.

Elías-Gutiérrez, M. and Valdez-Moreno, M. 2008. A new cryptic species of Leberis Smirnov, 1989 (Crustacea, Cladocera, Chydoridae) from the Mexican semi-desert region, highlighted by DNA barcoding. Hidrobiológica, 18(1): 63-74.

Elmoor-Loureiro, L.M.A. 1997. Manual de identificação de cladóceros límnicos do Brasil. Brasilia, Universia, 156p.
Elmoor-Loureiro, L.M.A.; Santos-Wisniewski, M.J. and Rocha, O. 2013. Redescription of Alonella lineolata Sars, 1901 (Crustacea, Cladocera, Chydoridae) and its translocation to the subfamily Aloninae and to the new genus Bergamina gen. nov.. Zootaxa, 3630(3): 571-581.

Espíndola, E.G.; Matsumura-Tundisi, T. and Moreno, I.H. 1996. Efeitos da dinâmica hidrológica do sistema Pantanal Matogrossense sobre a estrutura da comunidade de zooplâncton da lagoa Albuquerque. Acta Limnologica Brasiliensia, 8: 37-57.

Frutos, S.M.; Poi de Neiff, A.S.G. and Neiff, J.J. 2006. Zooplankton of the Paraguay River: a comparison between sections and hydrological phases. Annales de Limnologie - International Journal of Limnology, 42(4): 277-288.

Güntzel, A.M.; Panarelli, E.A.; Silva, W.M. and Roche, K.F. 2010. Influence of connectivity on Cladocera diversity in oxbow lakes in the Taquari River floodplain (MS, Brazil). Acta Limnologica Brasiliensia, 22(1): 93-101.

José de Paggi, S. and Paggi, J.C. 2007. Zooplankton. p. 229-249. In: M. Iriondo; J.C. Paggi and J. Parma (eds), The Middle Paraná River: Limnology of a Subtropical Wetland. Berlin, Heidelberg, Springer - Verlag.

Junk, W.J.; Piedade, M.T.F.; Lourival, R.; Wittmann, F.; Kandus, P.; Lacerda, L.D.; Bozelli, R.L.; Esteves, F.A.; Nunes da Cunha, C.; Maltchik, L.; Schöngart, J.; Schaeffer-Novelli, Y. and Agostinho, A.A. 2014. Brazilian wetlands: their definition, delineation, and classification for research, sustainable management, and protection. Aquatic Conservation: Marine and Freshwater Ecosystems, 24: 5-22.

Korovchinsky, N.M. 1997. On the history of studies on cladoceran taxonomy and morphology, with emphasis on early work and causes of insufficient knowledge of the diversity of the group. Hydrobiologia, 360: 1-11.

Kotov, A.A.; Sinev, A.Y. and Berrios, V.L. 2010. The Cladocera (Crustacea: Branchiopoda) of six high altitude water bodies in the North Chilean Andes, with discussion of Andean endemism. Zootaxa, 2430: 1-66.

Kotov, A.A.; van Damme, K.; Bekker, E.I.; Siboualipha, S.; Silva-Briano, M.; Ortiz, A.A.; De La Rosa, R. and Sanoamuang, L. 2013. Cladocera (Crustacea: Branchiopoda) of Vientiane province and municipality, Laos. Journal of Limnology, 72(s2): 81-108.

Lansac-Tôha, F.A.; Velho, L.F.M. and Lima, A.F. 1997. Comunidade zooplanctônica. p. 115-153. In: A.E.A.M. Vazzoler; A.A. Agostinho and N.S. Hahn (orgs), A planície de inundação do alto Rio Paraná: aspectos físicos, biológicos e socioeconômicos. 1ed. Maringá, EDUEM.

Lima, A.F.; Lansac-Tôha, F.A.; Velho, L.F.M.; Bini, L.M. and Takeda, A.M. 2003. Composition and abundance of Cladocera (Crustacea) assemblages associated with Eichhornia azurea (Swartz) Kunth stands in the Upper Paraná River floodplain. Acta Scientiarum, 25(1): 41-48. 
Lopez, C. 1993. First record of Ephemeroporus acanthodes Frey 1982 Crustacea: Cladocera for Venezuela. Acta Cientifica Venezolana, 44(5): 312-314.

Neves, I.F.; Rocha, O.; Roche, K.F. and Pinto, A.A. 2003. Zooplankton community structure of two marginal lakes of the River Cuiabá (Mato Grosso, Brazil) with analysis of Rotifera and Cladocera diversity. Brazilian Journal of Biology, 63(2): 329-343.

Paggi, J.C. 1972. Nota sistemática acerca del algunos Cladóceros del género Chydorus Leach 1843 de la Rep. Argentina. Physis, 31: 223-236.

Paggi, J.C. 1973. Contribución al conocimiento de los Cladóceros dulceacuícolas argentinos. Physis, 32: 105114.

Paggi, J.C. 1975. Sobre dos cladóceros Chydoridae nuevos para la fauna argentina. Physis B, 34: 133-150.

Paggi, J.C. 1995. Crustacea Cladocera. p. 909-951. In: E.C. Lopretto and G. Tell, (eds), Ecosistemas de aguas continentales. Metodologías para su estudio. III. La Plata, Ediciones Sur.

Paggi J.C. 2004. Importancia de la fauna de "Cladoceros" (Crustacea, Brachiopoda) del Litoral Fluvial Argentino. INSUGEO, 12: 5-12.

Paggi, J.C. and José de Paggi, S.B. 1974. Primeros estudios sobre el zooplancton de aguas lóticas del Paraná Medio. Physis B, 86(33): 91-114.

Paggi, J.C. and José de Paggi, S.B. 1990. Zooplankton of lotic and lentic environments of the Middle Paraná River. Acta Limnologica Brasiliensia, 3: 685-719.

Perbiche-Neves, G. and Nogueira, M.G. 2010. Multidimensional effects on Cladoceran (Crustacea, Anomopoda) assemblages in two cascade reservoirs in Southeast Brazil. Lakes and Reservoirs: Research and Management, 15: 139-152.

Rocha, O. and Güntzel, A.M. 1999. Crustáceos branquiópodos. p. 107-120. In: D. Ismael; W.C. Valenti; T. Matsumura-Tundisi and O. Rocha (eds), Biodiversidade do estado de São Paulo, Brasil. Invertebrados de Água doce. Vol. 4. São Paulo, FAPESP.

Rocha, O.; Santos-Wisniewski, M.J. and MatsumuraTundisi, T. 2011. Checklist de Cladocera de água doce do Estado de São Paulo. Biota Neotropica, 11(1a): http:// www.biotaneotropica.org.br/v1 $1 \mathrm{n} 1 \mathrm{a} / \mathrm{en} / \mathrm{abstract}$ ?invent ory+bn0271101a2011 - ISSN 1676-0603

Serafim-Júnior, M; Perbiche-Neves, G.; Brito, L. and Ghidini, A.R. 2006. Zooplâncton do rio Itajaí-Açú a jusante da cidade de Blumenau, Santa Catarina, Brasil. Estudos de Biologia, 28(65): 41-50.

Silva-Briano, M. and Dumont, H.J. 2001. Wlassicsia, Bunops and Onchobunops (Anomopoda), three related genera. Hydrobiologia, 442: 1-28.

Sinev. A.Y. 2009. Cladocerans of the Alona affinis (Leydig, 1860) group from South Africa. Zootaxa, 1990: 41-54.
Sinev, A.Y. and Elmoor-Loureiro, L.M.A. 2010. Three new species of chydorid cladocerans of subfamily Aloninae (Branchipoda: Anomopoda: Chydoridae) from Brazil. Zootaxa, 2390: 1-25.

Sinev, A.Y. and Korovchinsky, N.M. 2013. Cladocera (Crustacea: Branchiopoda) of Cat Tien National Park, South Vietnam. Journal of Limnology, 72(s2): 125-141.

Sinev, A.Y. and Kotov, A.A. 2012. New and rare Aloninae (Cladocera: Anomopoda: Chydoridae) from Indochina. Zootaxa, 3334: 1-28.

Smirnov, N.N. 1996. Cladocera: the Chydorinae and Sayciinae (Chydoridae) of the World. In: H.J. Dumont (ed), Guides to the Identification of the Microinvertebrates of the Continental Waters of the World, Vol. 11. Amsterdam, SPB Academic Publishing, $197 p$.

Sousa, F.D.R.; Elmoor-Loureiro, L.M.A. and MendonçaGalvão, L. 2013. Cladocerans (Crustacea, Anomopoda and Ctenopoda) from Cerrado of Central Brazil: Inventory of phytophilous community in natural wetlands. Biota Neotropica, 13(3): http://www. biotaneotropica.org.br/v13n3/en/abstract?inventory+ bn00413032013 - ISSN 1676-0603.

Sousa, F.D.R.; Elmoor-Loureiro L.M.A. and Palaoro, A.V. 2012. O gênero Nicsmirnovius (Cladocera, Chydoridae, Aloninae) na América do Sul e descrição de uma nova espécie relacionada ao complexo-fitzpatricki. p. 75. In: VII Congresso Brasileiro sobre Crustáceos, Belém, Brasil.

Van Damme, K.; Bekker, E.I. and Kotov, A.A. 2013. Endemism in the Cladocera (Crustacea, Branchiopoda) of Southern Africa. Journal of Limnology, 72: 440-463.

Van Damme, K. and Dumont, H.J. 2008. The 'true' genus Alona Baird, 1843 (Crustacea: Cladocera: Anomopoda): position of the $A$. quadrangularis-group and description of a new species from the Democratic Republic of Congo. Zootaxa, 1943: 1-25.

Van Damme, K. and Dumont, H.J. 2010. Cladocera of the Lençóis Maranhenses (NE - Brazil): faunal composition and a reappraisal of Sars' Method. Brazilian Journal of Biology, 70(3) (suppl.): 755-779.

Van Damme, K. and Eggermont, H. 2011. The Afromontane Cladocera (Crustacea: Branchiopoda) of the Rwenzori (Uganda-D. R. Congo): taxonomy, ecology and biogeography. Hydrobiologia, 676: 57-100.

Van Damme, K.; Kotov, A.A. and Dumont, H.J. 2010. A checklist of names in Alona Baird 1843 (Crustacea: Cladocera: Chydoridae) and their current status: an analysis of the taxonomy of a lump genus. Zootaxa, 2330: 1-6.

Van Damme, K.; Sinev, A.Y. and Dumont, H.J. 2011. Separation of Anthalona gen. n. from Alona Baird, 1843 (Branchiopoda: Cladocera: Anomopoda): morphology and evolution of scraping stenothermic alonines. Zootaxa, 2875: 1-64.

Submitted 06 January 2015 Accepted 29 April 2015 